\title{
Fenomenologi Penyampaian Surat Pemberitahuan Wajib Pajak Orang Pribadi Menurut Peraturan Perpajakan
}

\author{
Dewi Kirowati ${ }^{1}$, Nova Maulud Widodo ${ }^{2}$ \\ ${ }^{1}$ Komputerisasi Akuntansi, Politeknik Negeri Madiun, Jl.Serayu 84, Madiun, 63133 \\ E-mail: dewik@pnm.ac.id \\ ${ }^{2}$ Akuntansi, Politeknik Negeri Madiun, Jl.Serayu 84, Madiun, 63133 \\ E-mail: novamaulud@pnm.ac.id
}

\begin{abstract}
Penelitian ini bertujuan untuk mengetahui fenomena Wajib Pajak (WP) dalam membayar pajak orang pribadi. Fokus pada penelitian ini pada penyampaian Surat Pemberitahuan (SPT) Pajak menurut peraturan perpajakan. Peraturan perpajakan dalam hal ini adalah PMK No. 9/PMK.03/2018, yaitu adanya perubahan terkait penyampaian SPT wajib pajak pada tahun 2018. Penelitian ini dilakukan dengan melibatkan wajib pajak orang pribadi yang melaporkan SPT. Partisipan pada penelitian ini adalah Konsultan Pajak, Pengelola Brevet Pajak, dan Pegawai Politeknik Negeri Madiun. Penelitian ini menggunakan metode kualitatif, yaitu dengan fenomenologi transedental. Penelitian ini diharapkan dapat menjadi referensi dalam pelaporan pajak oleh wajib pajak orang pribadi. Peraturan perpajakan baru, yaitu PMK No. 9/PMK.03/2018 mengubah ketentuan PMK No. 243/PMK.03/2014 tentang Surat Pemberitahuan. Salah satu perubahan yang terkandung adalah pelaporan SPT Masa Nihil. Hasil penelitian menunjukan bahwa WPOP di Lingkungan Politeknik Negeri Madiun sebagian besar memiliki penghasilan pokok dibawah PTKP, namun pegawai di PNM masih menerima penghasilan lainnya. Sehingga, atas penghasilan tersebut Bendaharawan memotongkan PPh 21-nya lalu disetorkan. Namun untuk SPT pegawai pada penelitian ini, dilaporkan sendiri (Self Assesment) oleh WPOP disertai bukti potong dari Bendaharawan Institusi. Kehadiran peraturan perpajakan tersebut lebih memudahkan bagi WPOP maupun Bendaharawan Institusi dalam hal penyampaian SPT.
\end{abstract}

Keywords —: Surat Pemberitahuan (SPT); Wajib Pajak; Wajib Pajak Orang Pribadi; Regulasi Pajak.

\section{PENDAHULUAN}

Wajib Pajak adalah orang pribadi atau badan, meliputi pembayar pajak, pemotong pajak, dan pemungut pajak, yang mempunyai hak dan kewajiban perpajakan sesuai dengan ketentuan peraturan perundang-undangan perpajakan. Warga Negara memiliki tanggung jawab dibidang perpajakan. Warga negara sebagai wajib pajak wajib mengukuhkan dirinya dengan memiliki nomor pokok wajib pajak.

Sistem pemungutan pajak yang berlaku di Indonesia adalah sistem self assessment. Self assessment maksudnya setiap Wajib Pajak bertanggungjawab sepenuhnya terhadap kewajiban pembayaran pajak, pelaporan pajak, dan pemberitahuan pajak yang terutang kepada pemerintah, yang sesuai dengan undang-undang perpajakan yang berlaku. Semua Wajib Pajak yang telah memenuhi persyaratan subjektif dan objektif sesuai dengan ketentuan peraturan perundang-undangan perpajakan berdasarkan sistem self assessment, wajib mendaftarkan diri pada kantor Direktorat Jenderal Pajak untuk dicatat sebagai Wajib Pajak (WP) dan sekaligus untuk mendapatkan Nomor Pokok Wajib Pajak (NPWP).

Pajak memiliki peranan penting dalam bernegara, penerimaan Anggaran Pendapatan dan Belanja Negara (APBN) terbesar bersumber dari pajak. Pajak dalam pelaksanaan pembangunan sangat penting karena pajak merupakan sumber pendapatan negara untuk membiayai semua pengeluaran termasuk pengeluaran pembangunan. Peran pajak ini dapat dilihat dari fungsi pajak itu sendiri. Menurut Mardiasmo (2011: 1), ada dua fungsi pajak, yaitu fungsi budgetair sebagai sumber dana bagi pemerintah untuk membiayai pengeluaran- pengeluarannya. Fungsi mengatur (regulerend) sebagai alat untuk mengatur atau melaksanakan kebijaksanaan pemerintah dalam bidang sosial dan ekonomi, seperti pajak yang tinggi dikenakan terhadap minuman keras untuk mengurangi konsumsi minuman keras, pajak yang tingggi dikenakan terhadap barang-barang mewah untuk mengurangi gaya hidup konsumtif.

Penerimaan pajak merupakan sumber utama pendapatan negara dalam pembiayaan pemerintah dan pembangunan. Pajak bertujuan meningkatkan kesejahteraan rakyat melalui perbaikan dan peningkatan sarana publik. Alokasi pajak tidak hanya diberikan kepada rakyat yang membayar pajak tetapi juga untuk kepentingan rakyat yang tidak membayar pajak. Dengan demikian, peranan penerimaan pajak bagi suatu negara menjadi sangat dominan dalam menunjang jalannya roda pemerintahan.

Lembaga yang ditunjuk untuk mengelola pajak, dalam hal ini adalah Direktorat Jenderal Pajak (DJP) dibawah Kementerian Keuangan Republik Indonesia. Target penerimaan pajak senantiasa mengalami peningkatan dari tahun ke tahun. Pada tahun 2017 target penerimaan pajak sebesar Rp 1.498 T, naik sebesar 15\% dari tahun 2016 (finance.detik.com. 2016). Adanya tuntutan akan peningkatan penerimaan pajak mendorong Ditjen Pajak terus melakukan reformasi perpajakan berupa penyempurnaan terhadap kebijakan perpajakan dan sistem administrasi perpajakan sehingga potensi penerimaan pajak yang 
Website : http://ekomaks.unmermadiun.ac.id/index.php/ekomaks

tersedia dapat dipungut secara optimal dengan menjunjung asas keadilan sosial serta memberikan pelayanan prima kepada wajib pajak.

Dalam mewujudkan sistem administrasi perpajakan modern, pemerintah menyediakan aplikasi yang dapat digunakan oleh wajib pajak untuk melakukan pengisian dan pelaporan Surat Pemberitahuan Tahunan (SPT) secara cepat, tepat dan akurat. Adanya perkembangan teknologi informasi yang semakin canggih yang dalam hal ini ditandai dengan era digital menjadikan peluang sekaligus tantangan bagi DJP untuk senantiasa menyesuaikan diri. Permasalahan yang terjadi sebelumnya adalah antrian penyampaian SPT dari wajib pajak yang memasuki jatuh tempo pelaporan dan petugas perekaman data SPT di Kantor Pelayanan Pajak (KPP) Pratama yang jumlahnya terbatas sehingga proses perekaman menjadi lambat dan bahkan menjadi tunggakan perekaman. Selain itu dapat terjadi kesalahan (human error) dalam proses perekaman data ulang secara manual oleh fiskus. Reformasi administrasi perpajakan dilakukan oleh DJP sebagai bentuk peningkatan kualitas pelayanan perpajakan terhadap wajib pajak, salah satunya dikembangkannya pelaporan pajak terutang dengan menggunakan elektronik SPT (e-SPT).

Terkait dengan tugas pemungutan pajak, negara mempunyai wewenang hukum untuk meminta orang-orang yang berada di bawah yurisdiksi kedaulatannya menyumbangkan sebagian sumber dayanya untuk menutup pengeluaran pemerintah. Demikian juga, setiap warga negara harus membayar pajak dan orang yang menghindari kewajiban ini dapat dikenakan denda. Dalam rangka pemenuhan kewajiban perpajakan yang harus dilakukan masyarakat atau Wajib Pajak (WP), pengelolaan pajak harus dilakukan dengan baik dan benar sesuai dengan ketentuan perundang-undangan perpajakan yang berlaku saat ini. Hal ini dimaksudkan agar masyarakat atau Wajib Pajak terhindar dari pengenaan sanksi perpajakan baik sanksi administrasi maupun sanksi pidana.

Pemungutan pajak bukan pekerjaan yang mudah disamping peran aktif dari petugas perpajakan, juga dituntut kesadaran dari Wajib Pajak (WP) itu sendiri. Penyebab kurangnya kemauan membayar pajak antar lain asas perpajakan yaitu bahwa hasil pemungutan pajak tersebut tidak secara langsung dapat dinikmati oleh para Wajib Pajak. Hal ini terjadi karena masyarakat tidak pernah mengetahui wujud konkret imbalan dari uang yang dikeluarkan untuk membayar pajak. Sehingga Wajib Pajak melaksanakan pembayaran pajak bukan karena kesadarannya melainkan karena takut akan dendanya.

Penerimaan perpajakan mengalami peningkatan yang cukup signifikan baik secara nominal maupun secara persentase terhadap seluruh pendapatan negara. Hal ini sangat rasional karena pada kenyataannya rasio antara jumlah Wajib Pajak (WP) dengan jumlah penduduk serta jumlah usaha masih sangat kecil. Untuk mencapai target pajak, perlu ditumbuhkan terus menerus kesadaran dan kepatuhan masyarakat untuk memenuhi kewajiban pajak sesuai dengan ketentuan yang berlaku.

Kemauan Wajib Pajak dalam membayar pajak merupakan hal yang penting. Hal ini didasarkan pada Self Assessment System yaitu sistem pemenuhan kewajiban perpajakan, yaitu Wajib Pajak melaksanakan sendiri kewajiban perpajakannya sesuai dengan data dan informasi yang ada padanya serta berdasarkan ketentuan perundang- undangan perpajakan yang berlaku, dalam sistem ini Wajib Pajak harus aktif menghitung, memperhitungkan, membayar, melaporkan sendiri pajaknya. Penerapan Self Assessment System menyebabkan kebenaran pembayaran pajak tergantung pada kejujuran Wajib Pajak sendiri dalam pelaporan kewajiban pajaknya.

Penerapan self assessment system membutuhkan kepatuhan pajak sukarela (Saad, 2014). Kepatuhan pajak sukarela ini juga meliputi keharusan untuk memahami undang-undang perpajakan, menghitung dan membayar jumlah pajak yang tepat sesuai peraturan yang berlaku, termasuk melakukan pencatatan yang benar (Sapiei dan Kasipillai, 2013). Segala ketetapan DJP termasuk penerapan sistem perpajakan harus diikuti oleh wajib pajak.

Kemauan membayar pajak dapat diartikan sebagai suatu nilai yang rela dikontribusikan oleh seseorang yang ditetapkan dengan peraturan digunakan untuk membiayai pengeluaran umum negara dengan tidak mendapat jasa timbal secara langsung. Kesadaran membayar pajak di Indonesia semakin membaik karena target penerimaan negara tahun 2017 terealisasi $91 \%$ dari target yang dianggarkan oleh Kementerian keuangan (finance.detik.com., 2018).

Adanya kesadaran dan kemauan membayar pajak yang meningkat ini direspon DJP dengan munculnya berbagai peraturan perpajakan. Kehadiran peraturan perpajakan ini bertujuan untuk mengatur berbagai aktivitas terkait perpajakan. Adanya peraturan perpajakan yang baru diharapkan agar penerimaan negara yang bersumber dari pajak semakin meningkat. Sehingga proses pelaporan pajak dibuat semakin mudah. Salah satu peraturan tersebut adalah PMK No. 9/PMK.03/2018 mengubah ketentuan PMK No. 243/PMK.03/2014 tentang Surat Pemberitahuan. Berdasarkan latar belakang inilah, maka penulis tertarik melakukan penelitian dengan tujuan untuk mengetahui perkembangan regulasi terkait perpajakan kemudian mengetahui tanggapan dan dampak perubahan regulasi terhadap penyampain SPT WPOP.

\section{METODOLOGI PENELITIAN}

\section{A. Pendekatan Penelitian}

Jenis pendekatan yang digunakan dalam penelitian ini adalah pendekatan kualitatif. Melalui pendekatan kualitatif, peneliti dapat mengenali subjek, merasakan apa yang dialami individu dalam kehidupan sehari- hari. Terdapat Pendekatan yang digunakan adalah fenomenologi. Fenomenologi merupakan pandangan berpikir yang menekankan pada fokus kepada pengalaman-pengalaman subjektif manusia dan interpretasi-interpretasi dunia (Moleong, 2011:15). Pada penelitian ini menggunakan fenomenologi transendental karena tipe ini berorientasi pada penemuan makna dan hakikat dari pengalaman. Hal ini dikarenakan, terdapat perbedaan antara fakta dan esensi dalam fakta, atau dengan kata lain perbedaan antara yang real dan yang tidak (Kuswarno, 2009:40). 


\section{Website : http://ekomaks.unmermadiun.ac.id/index.php/ekomaks}

Metode kualitatif memandang realitas sosial dan humaniora adalah sesuatu yang holistik, utuh, kompleks, dinamis, dan penuh makna. Oleh karena itu, metode kualitatif ini seringkali disebut sebagai metode naturalistik karena penelitiannya dilakukan pada kondisi realitas sosial alamiah. Objek alamiah adalah objek yang apa adanya, tidak dimanipulasi oleh peneliti (Roekhudin, 2013).

Ciri lain penelitian kualitatif adalah menggunakan manusia (diri peneliti) sebagai instrumen penelitian. Yang berati, peneliti harus terlibat langsung dengan sumber data (objek) yang diteliti dengan melakukan observasi dan wawancara mendalam dengan informan. Data yang dihasilkan dari proses ini berupa data kualitatif dan oleh karena itu analisis dan interpretasi data bersifat induktif dengan lebih mengedepankan intuisi dan refleksi. Simpulan yang dihasilkan bukan untuk tujuan generalisasi, tetapi merupakan sebuah sintesis yang mengutamakan makna di balik fenomena.

Paradigma fenomenologi menganggap dunia sebagai sebagai sesuatu yang tidak pasti dan penuh problematika. Hal ini berbeda dengan metode normatif yang melihat dunia sebagai sesuatu yang pasti dan tidak problematik (Roekhudin, 2013). Hal tersebut berdampak pada cara memandang persoalan yang harus dijawab. Paradigma fenomenologi identik dengan menjelaskan 'lived experience' atau pengalaman hidup yang subjektif dan bukan generalisasi sebagai tujuannya. Hal terpenting dalam pandangan fenomenologi adalah bagaimana 'lived experience' menjelaskan secara lugas, sesuai adanya, tanpa presuposisi dan simplifikasi metodelogi yang cenderung mengaburkan naturalitas pengalaman.

Berdasar pada pemahaman yang telah dijelaskan, untuk mengetahui bentuk dan sekaligus untuk mengungkap makna di balik fenomena yang berkembang di lingkungan akuntan publik (auditor) terhadap penerapan fair value sebagai pengukuran dalam akuntansi tidak cukup diinvestigasi menggunakan data pasar modal. Pendekatan ini juga dipandang sangat sesuai digunakan sebagai metodelogi dalam penelitian ini, karena metode ini tidak terikat secara kaku mengikuti pola- pola tertentu sebagaimana yang diterapkan dalam metode kuantitatif. Penelitian dengan pendekatan fenomenologi tidak membuktikan benar atau salah. Fenomenologi berusaha untuk menemukan hakekat atau makna kesadaran informan dalam memahami fenomena, yang disebut dengan pengetahuan murni.

\section{B. Jenis dan Sumber Data}

\section{Data primer}

Data primer pada penelitian ini diperoleh langsung dari obyek penelitian atau lapangan diantaranya dengan cara menggunakan wawancara kepada partisipan. Partisipan merupakan pengelola brevet pajak dan pegawai di Lingkungan Politeknik Negeri Madiun. Kemudian peneliti juga mewanwancarai konsultan pajak anggota IKPI.

\section{Data sekunder}

Merupakan data yang telah tersedia sebagai pendukung data yang digunakan dalam penelitian. Data sekunder adalah datadata yang didapat dari sumber bacaan dan berbagai macam sumber lainnya yang terdiri dari surat-surat pribadi, buku harian, notula rapat perkumpulan, sampai dokumen-dokumen resmi dari berbagai instansi pemerintah. Data sekunder juga dapat berupa majalah, buletin, publikasi dari berbagai organisasi, lampiran-lampiran dari badan-badan resmi seperti kementriankementrian, hasil-hasil studi, tesis, hasil survey, studi historis.

Peneliti menggunakan data sekunder ini untuk memperkuat penemuan dan melengkapi informasi yang telah dikumpulkan melalui wawancara langsung dengan partisipan.

\section{Teknik Pengumpulan Data}

Metode pengumpulan data dalam penelitian ini dimaksudkan untuk memperoleh data yang relevan dan akurat dengan masalah yang dibahas. Pengumpulan data merupakan langkah yang sangat penting dalam penelitian, karena itu seorang peneliti harus terampil dalam mengumpulkan data agar mendapatkan data yang valid. Pengumpulan data adalah prosedur yang sistematis dan standar untuk memperoleh data yang diperlukan. Teknik pengumpulan data yang dilakukan antar lain:

\section{a. Observasi Langsung}

Observasi langsung adalah cara pengambilan data dengan menggunakan mata tanpa ada pertolongan alat standar lain untuk keperluan tersebut.

Observasi ini digunakan untuk penelitian yang telah direncanakan secara sistematik tentang bagaimana dampak adanya peraturan perpajakan yang baru di Lingkungan Politeknik Negeri Madiun. Observasi langsung juga dapat memperoleh data dari subjek baik yang tidak dapat berkomunikasi secara verbal atau yang tak mau berkomunikasi secara verbal.

\section{b. Wawancara}

Wawancara yaitu dialog secara langsung untuk memperoleh informasi dari responden terpilih dalam menghimpun informasi yang relevan dengan penelitian. Wawancara merupakan proses memperoleh keterangan untuk tujuan penelitian dengan cara tanya jawab, sambil bertatap muka antara si penanya dengan si penjawab dengan menggunakan alat yang dinamakan interview guide (panduan wawancara).

Tujuan penulis menggunakan metode ini, untuk memperoleh data secara jelas dan kongkret tentang bagaimana fenomena hadirnya peraturan perpajakan terkait surat pemberitahuan pajak pada lingkungan Politeknik Negeri Madiun. 
Website : http://ekomaks.unmermadiun.ac.id/index.php/ekomaks

Tabel 1. Tabel Partisipan

\begin{tabular}{ccc}
\hline No & Nama & Posisi \\
\hline 1 & Bapak LILIK & Konsultan Pajak \\
2 & Ibu Sugiyanti & Tutor Brevet Pajak \\
3 & Mbak Eska & Bendahara Politeknik Negeri Madiun \\
4 & Sugiharto,SE,MSA,Ak,CA,CPA. & Pengelola Brevet Pajak \\
5 & Qimyatussa'adah, SE, MSA & Pengelola Brevet Pajak
\end{tabular}

Sumber: Data Peneliti

\section{Desain Penelitian}

Pendekatan yang digunakan adalah fenomenologi. Fenomenologi merupakan pandangan berpikir yang menekankan pada fokus kepada pengalaman-pengalaman subjektif manusia dan interpretasi-interpretasi dunia (Moleong, 2011:15). Pada penelitian ini menggunakan fenomenologi transendental karena tipe ini berorientasi pada penemuan makna dan hakikat dari pengalaman. Hal ini dikarenakan, terdapat perbedaan antara fakta dan esensi dalam fakta, atau dengan kata lain perbedaan antara yang real dan yang tidak (Kuswarno, 2009:40).

Penelitian fenomenologis fokus pada sesuatu yang dialami dalam kesadaran individu, yang disebut sebagai intensionalitas. Intensionalitas (intentionality), menggambarkan hubungan antara proses yang terjadi dalam kesadaran dengan obyek yang menjadi perhatian pada proses itu. Dalam fenomenologi, pengalaman atau kesadaran selalu kesadaran pada sesuatu, melihat adalah melihat sesuatu, mengingat adalah mengingat sesuatu, menilai adalah menilai sesuatu. Sesuatu itu adalah obyek dari kesadaran yang telah distimulasi oleh persepsi dari sebuah obyek yang "real" atau melalui tindakan mengingat atau daya cipta (Smith, et.al , 2009: 12). Intensionalitas tidak hanya terkait dengan tujuan dari tindakan manusia, tetapi juga merupakan karakter dasar dari pikiran itu sendiri. Pikiran tidak pernah pikiran itu sendiri, melainkan selalu merupakan pikiran atas sesuatu. Pikiran selalu memiliki obyek. Hal yang sama berlaku untuk kesadaran. Intensionalitas adalah keter-arahan kesadaran (directedness of consciousness). Intensionalitas juga merupakan keter-arahan tindakan, yakni tindakan yang bertujuan pada satu obyek.

Data dari fenomena sosial yang diteliti dapat dikumpulkan dengan berbagai cara, diantaranya observasi dan interview, baik interview mendalam. Interview mendalam dalam penelitian fenomenologi bermakna mencari sesuatu yang mendalam untuk mendapatkan satu pemahaman yang mendetail tentang fenomena sisoal dan pendidikan yang diteliti. Interview mendalam juga bermakna menuju pada sesuatu yang mendalam guna mendapatkan rasa dari yang nampaknya mudah secara aktual secara potensial lebih complicated. Pada sisi lain peneliti juga harus memformulasikan kebenaran peristiwa/ kejadian dengan pewawancaraan mendalam ataupun interview. Data yang diperoleh dengan in-depth interview dapat dianalisis proses analisis data dengan Interpretative Phenomenological Analysis.

\section{Kehadiran Peneliti}

Dalam penelitian ini, peneliti bertindak sebagai pengumpul data dan sebagai instrumen aktif dalam upaya mengumpulkan datadata di lapangan. Sedangkan instrumen pengumpulan data yang lain selain manusia adalah berbagai bentuk alat-alat bantu dan berupa dokumen-dokumen lainnya yang dapat digunakan untuk menunjang keabsahan hasil penelitian, namun berfungsi sebagai instrumen pendukung.

\section{E. Lokasi Penelitian}

Lokasi penelitian adalah tempat di mana penelitian akan dilakukan. Dalam penelitian ini, peneliti berfokus pada wilayah Madiun, yakni pada Lingkungan Politeknik Negeri Madiun.

\section{F. Teknik Analisis Data}

Analisis deskriptif- kualitatif merupakan suatu teknik yang menggambarkan dan menginterpretasikan arti data-data yang telah terkumpul dengan memberikan perhatian dan merekam sebanyak mungkin aspek situasi yang diteliti pada saat itu, sehingga memperoleh gambaran secara umum dan menyeluruh tentang keadaan sebenarnya.

Menurut Nazir (2005) tujuan deskriptif adalah untuk membuat deskripsi, gambaran atau lukisan secara sistematis, faktual dan akurat mengenai fakta- fakta, sifat- sifat serta hubungan antar fenomena yang diselidiki. Oleh karena penelitian ini menggunakan fenomenologi, maka tahapan analisis dilakukan dengan mengacu pada model analisis Moustakas (1994).

\section{III.HASIL DAN PEMBAHASAN}

\section{A. Hasil Penelitian}

Penelitian ini bertujuan untuk mengetahui fenomena Wajib Pajak (WP) dalam membayar pajak orang pribadi. Fokus pada penelitian ini adalah penyampaian Surat Pemberitahuan (SPT) Pajak menurut peraturan perpajakan. Peraturan perpajakan, khususnya dalam hal penyampaian SPT pada tahun 2018 mengalami perubahan.

Konsep modernisasi administrasi perpajakan pada prinsipnya adalah merupakan perubahan pada sistem administrasi perpajakan yang dapat mengubah pola pikir dan perilaku fiskus serta tata nilai organisasi sehingga dapat menjadikan Direktorat Jenderal Pajak (DJP) menjadi suatu institusi yang profesional dengan citra yang baik di masyarakat. Perwujudan pelaksanaan 
sistem self assessment dibidang perpajakan adalah pelaporan Surat Pemberitahuan pajak (SPT) terutang kepada pemerintah yang secara langsung disampaikan oleh Wajib Pajak yang bersangkutan. SPT ini harus disampaikan oleh Wajib Pajak dengan benar kepada Ditjen Pajak sesuai dengan peraturan perundang-undangan perpajakan yang berlaku.

Pada penelitian ini, peneliti menggunakan metode kualitatif yaitu memandang realitas sosial dan humaniora adalah sesuatu yang holistik, utuh, kompleks, dinamis, dan penuh makna. Oleh karena itu, metode kualitatif ini seringkali disebut sebagai metode naturalistik karena penelitiannya dilakukan pada kondisi realitas sosial alamiah. Objek alamiah adalah objek yang apa adanya, tidak dimanipulasi oleh peneliti (Roekhudin, 2013).

Paradigma fenomenologi menganggap dunia sebagai sebagai sesuatu yang tidak pasti dan penuh problematika. Hal ini berbeda dengan metode normatif yang melihat dunia sebagai sesuatu yang pasti dan tidak problematik (Roekhudin, 2013). Hal tersebut berdampak pada cara memandang persoalan yang harus dijawab. Tehnik pengumpulan data dilakukan dengan observasi, digunakan untuk penelitian yang telah direncanakan secara sistematik tentang bagaimana dampak adanya peraturan perpajakan yang baru di Lingkungan Politeknik Negeri Madiun. Selanjutnya dengan wawancara terhadap Pengelola Pajak dan Konsultan Pajak. Selain itu kami juga mengumpulkan dokumentasi dari konsultan pajak dan pegawai Politeknik Negeri Madiun.

Hasil penelitian ini sebagai berikut, menurut pendapat Ibu Yanti. Di PMK no 9 tahun 2018 itu yang diatur disana tidak hanya WP Orang Pribadi saja Pph 21 dan PPn itu wajib e-filling. Kemudian kalau aplikasinya wajib e-SPT semua. Tentunya ada sisi positif dan sisi negatif. Positifnya semakin mudah WP untuk lapor. Cuman ada kendalanya kan tidak semua orang bisa lapor online, tidak semua orang bisa menggunaka komputer apalagi aplikasi e-SPT. Jadi masih banyaj WP yang belum bisa lapor secara online. Kemudian kalau misalkan WP tidak bisa lapor secara online, alternatifnya makaWPOP harus datang langsung ke KPP.

Kalau di PMK No 9 itu sebenarnya lebih memudahkan administrasi (paperless) jadi tidak perlu ngeprint berlembar- lembar sudah cukup pakai aplikasi. Sehingga bisa hemat waktu, bisa lapor dimanapun dan kapanpun 24 jam. PMK no 9 tahun 2018 itu sendiri di dalamnya memuat penjelasan bahwa WPOP yang penghasilannya kurang dari PTKP tidak perlu lapor. Namun hal ini ada syaratnya. Bisa tidak wajib lapor tapi harus pengajuan Wajib Pajak NE (Non efektif) dulu.

Sebelum mengajukan NE, kewajiban lapor pajak masih berlaku. Sebelum dihapuskan kewajiban lapor harus di NE kan dulu. Kalau sudah disetujui baru tahun berikutnya tidak wajib lapor. Cuma kalau di tahun berjalan si WP terima potong dari pihak ketiga maka otomatis NPWP nya sudah aktif tanpa pemberitahuan ke WP. Kemudian selain PMK no 9, ada yang terbaru di peraturan DJP. Perihal PPn untuk pengusaha kena pajak yang bukan eceran, wajib mencantumkan NIK jika pembelinya tidak mempunyai NPWP. Itu terakhir kemarin berlaku mulai 1 April 2018. Sebelumnya berlaku 1 Desember 2017 kemudian diundur 1 April 2018. Sampai saat ini Ibu Yanti kurang tau diundur lagi atau tidak. Cuman yang diundur terakhir itu yang pelaporan online SPT PPh 21 dan PPn kan awalnya berlaku per 1 April itu memang diundur sampai 1 Mei. Karena sampai saat ini pun website DJP error. Karena mungkin terlalu banyak yang mengakses.

Menurut pengalaman Ibu Yanti sebagai konsultan pajak, pelaporan masyarakat Indonesia sudah berada pada kategori patuh, hanya saja nilai yang dilaporkan masih perlu pembinaan lagi. Untuk itu peran Pemerintah melalui DJP perlu ditingkatkan lagi. Solusinya, kalau tiap ada peraturan yang baru semua KPP segera mensosialisasikan kepada wajib pajak. Karena termasuk DER, TP-doc, dan e-Filling, e-SPT itu juga saya rasa banyak wajib pajak yang tidak tahu. Termasuk juga yang NE tadi. Selain itu lembaga pendidikan juga perlu mendukung kesadaran bayar pajak pada masyarakat.

Kemudian hasil wawancara peneliti dengan pengelola brevet di Politeknik Negeri Madiun (PNM) diantaranya adalah pelaksanaan brevet pajak di PNM. Pelaksanaan Brevet pajak periode pertama tahun 2016 ada 1 Angkatan, terus 2017 ada 2 angkatan, 2018 sedang berjalan angkatan ke 5. Untuk pemilihan tutor dipilih berdasarkan kerjasama antar institusi dengan IKPI, jadi memang sudah ada MOU nya disitu dan sudah lengkap bentuk kerjasamanya dalam butir-butir MOU itu sudah ditandatangani oleh direktur dengan ketua IKPI nya sendiri. Kemudian untuk pemilihan tutor itu tadi berdasarkan MOU, yang kedua tutor adalah yang usdah memiliki seritifikat BKP, kemudian yang ketiga keterjangkauan waktu tutor di Madiun. Jadi pernah beberapa saat tutor didatangkan dari Malang karena yang di Madiun tidak bisa mengcover jadwal yang diberikan.

Pelaksanaan pelatihan brevet di PNM sudah kekinian. Terbukti dengan melakukan pembaharuan pada modul. Jadi baik secara tertulis maupun secara lisan dan proses pengajaran di kelas semuanya itu memang update dengan aturan terkini. Seperti misalnya pengisian SPT secara online itu juga dari pihak tutor juga sudah menyediakan aplikasi yang bisa digunakan untuk edukasi di kelas.

Harapan pengelola terhadap peserta brevet agar mereka punya skill tambahan dalam memahami peraturan perpajakan yang pertama. Yang kedua penerapan keilmuannya sehingga bisa dimanapun mereka bekerja di entitas apapun mereka paham aturan pajak dan bagaimana caranya mengikuti peraturan tersebut. Jadi termasuk menghitung. Menyetorkan mereka paham bagaimana prosesnya.

Kaitannya dengan PMK No 9 tahun 2018 menurut pendapat Ibu Qim, bahwasannya WPOP yang notabene nihil ini tidak perlu melaporkan surat pemberitahuan pajaknya. Menurut pendapat bu Qim dalam sudut pandang penerimaan, kemudahan lebih baik daripada sebelum terbitnya peraturan tersebut.

"Iya lebih mudah daripada sebelumnya. Karna kalau nihil kan terus kita harus lapor lagi, ndak praktis. Sekarang kan jadinya lebih mudah. Dan yang harusnya jadi sorotan kan entitas-entitas besar yang memang nunggak-nunggak pajak" Tutur BU Qim

Kemudian terdapat tanggapan dari ketua pengelola Brevet Politeknik Negeri Madiun, Bapak Sugiharto.

"Perpajakan itu sangat erat hubungannya dengan sebuah peraturan (rules of based). Peraturan disini saya melihat bahwa tahun 2018 ada PMK yang baru, yaitu PMK no 9 tahun 2018. Ini kaitannya dengan penyampian SPT tahunan, SPT masa. 
Website : http://ekomaks.unmermadiun.ac.id/index.php/ekomaks

Kemudian titik utamanya ini yang perlu saya tanyakan terlebih dahulu apakah dari pihak pengelola pajak ini melakukan penekanan kepada para tutor kaitannya dengan update materi? 'tanya peneliti.

Menanggapi pertanyaan dari peneliti tersebut, ketua pengelola brevet memiliki "pendapat yang kritis". Hadirnya peraturan abu abu oleh pemerintah Indonesia, tentunya mendapat penolakan oleh bapak Sugiharto. Berikut pendapatnya:

"Itu otomatis kalau pas update materi pasti harus diperbaiki terus menyesuaikan peraturan. Karena pajak itu idak hanya terkait dengan hanya bagaimana menyampaikan SPT tapi melekat pada transaksi, sehingga pajak itu sangat berpengaruh terhadap transaksi ekonomi. Sehingga semua kebijakan yang menyangkut pajak pasti dikaitkan dengan ekonomi. Contohnya, dulu undang- undang no 36 tahun 2018 tentang pajak badan dulu tarifnya progresif 5\%, $10 \%$ sampai 25\%. Sekarang tunggal. Tunggal ini dianggap memberatkan wajib pajak sehingga keluar PP 46. 1 \% dari omset. Itulah mengikuti fleksibel engikuti perkembangan ekonomi. Misalnya PTKP pemerintah mewajibkan seluruh wajib pajak memiliki NPWP tapi aturan yang terbaru tidak mewajibkan jika dibawah PTKP. Ini sering saya sampaikan ke seminar pajak atau workshop. Kenapa sih membuat peraturan perpajakan di Indonesia itu kok membuat orang ada celah untuk main. Kong kali kong antara fiskus dengan WP ya contohnya itu tadi. Peraturannya itu abu-abu kalau saya bilang di Indonesia itu. Kenapa kalau boleh ya boleh. Contohnya WP semua NPWP harus dimiliki oleh WP tapi aturan yang terabaru jika tidak diatas PTKP tidak wajib mempunyai NPWP.

Bisa dinonaktifkan. Ada artinya yaitu berbeda to antara peraturan satu dengan peraturan yang lainnya. Itulah yang saya tidak suka aturan pajak di Indonesia. Makanya termasuk ini nanti kalau ada seminar, bagaimana membangun bangsa itu salah satunya dengan hal kecil kaya gini. Padahal kan kedepannya nanti penerimaan negara yang palig utama itu dari pajak. Kebetulan aja Indonesia itu sumber alamnya subur. Sehingga tidak dominan penerimaan pajak. Tapi kedepannya hutan kan habis, batubara habis, premium habis ya to? Kalau ini semua habis dan tidak bisa diperbaharui penerimaan negara itu harus mengandalkan dari pajak. Coba to lihat negara yang maju eropa itu dari pajak. Di Indonesia ini belum bisa di kelola dengan maksimal penerimaan negara dari pajak. Lha makanya ini tugas kita bersama sebagai generasi bangsa entah itu dosen, mahasiswa atau regulasi di fiskus maksud saya. Itu justru harus menggali.

Makanya saya nggak setuju peraturan itu bahwa WP yang tidak diatas PTKP boleh membekukan NPWP. Saya tidak setuju. Justru NPWP itu, lahir ceprot harus sudah punya NPWP rakyat Indonesia itu. Dikasih nomor NPWP, dikasih nomor KTP. Sehingga bisa memantau penghasilan seseorang itu. Sehingga bisa memaksimalkan penerimaan pajak. Saya tidak setuju aturan itu. Makanya saya di seminar-seminar itu paling ngomong kenceng mengenai aturan di Indonesia. Contohnya yang sedikit penyusustan saja. Kenapa kok harus ada penyusutan pajak? Kenapa kok ndak diseragamkan antara komersial dengan fiskal? Harus digolongkan 1, golongkan 2 kok ndak mengikuti salah satu. Itu dari sisi penyusutan. Terus dari sisi tarif. Ya oke tarif pajak saya memaklumi ya karena menyesuaikan kondisi kemampuan WP. Tapi saya yang tidak setuju ini aturan yg terbaru. Kalau penghasilan dibawah PTKP (nihil) tidka perlu lapor. Lha kalau gitu kan kehilangan rekam jejak. Yang benar itu walaupun nihil juga wajib lapor. Sehingga WP ini merasa dipantau. Lha karena orang itu kecenderungan membayar pajak itu tidak mau sebetulnya. Gitu lho, lha ini justru aturannya ini yang tegas. Inilah kelemahan regulasi pajak di Indonesia menurut saya. Makanya saya nggak tertarik sama sekali aturan pajak terbaru itu. PMK no 9 tahun 2018.

Tadi sudah saya sampaikan walaupun nihil tidak melaporkan, karena kecenderungannya WP kan tidak direpotin. Cuman kalau ini nanti diteruskan kita sebetule kehilangan jejak rekam. Menurut saya nihil atau tidak nihil WP harus lapor dan setor ya. Makaya saya tidak setuju dengan PMK no 9 tahun 2018."

Kemudian informasi terakhir adalah pelaksanaan SPT setelah terbitnya PMK No 9 tahun 2018 di Lingkungan Politeknik Negeri Madiun. Untuk mendapatkan data ini, kami melakukan selidik dan dokumentasi dengan "Mbak Eska" selaku bagian keuangan di Politeknik Negeri Madiun. Berikut hasil observasi kami.

"Di pasal 10(2) itu kan menitik beratkan pada pelaporan SPT PPh 21/26. Karena PNM tidak ada tenaga kerja asing, sehingga kami hanya melaporkan SPT PPh 21 saja. Alhamdulillah selama ini saya bekerja di Poltek, kami belum pernah mengalami SPT PPh 21 nihil. Karena walaupun penghasilan pokok seluruh pegawai PNM ini dibawah PTKP, namun.... Pegawai PNM masih menerima jenis penghasilan lainnya. Sehingga atas penghasilan yag diterima tersebut tetap kami potong pph 21nya, lalu kami setorkan dan kami laporkan. Untuk bulan Desember tiap tahunnya, kami tetap melaporkan SPT Tahunan PPh 21 atas seluruh penghasilan yang diterima oleh seluruh pegawai PNM. Dan kami buatkan Bukti potong untuk setiap individu, agar mereka dapat melaporkan SPT PPh 21 mereka dengan Mandiri.”

\section{B. Pembahasan penelitian}

Berdasarkan hasil penelitian, kita ketahui berbagai pendapat terkait terbitnya peraturan perpajakan di Indonesia. Terlebih hadirnya PMK No 9 Tahun 2018 tentang surat pemberitahuan pajak terutang. Penjelasan PMK No 9 Tahun 2018 oleh konsultan pajak diketahui terdapat sisi positf dan negatif. Sisi positifnya adalah kemudahan dan sisi negatifnya adalah keterbatasan sumber daya manusia. Keberadaan peraturan pajak yang mengharuskan pelaporan pajak secara online lebih memudahkan, lebih paperless, bisa diakses kapanpun dan dimanapun. Semua partisipan sepakat dengan kesimpulan kemudahan adannya peraturan baru tersebut.

Selain pandangan positif terhadap kehadiran peraturan baru tersebut, juga terdapat pandangan yang berbeda. Salah satunya oleh ketua pengelola brevet pajak Politeknik Negeri Madiun. Bapak Sugiharto dengan kritis menolak kehadiran peraturan yang dapat menimbulkan celah bagi wajib pajak. Terlebih hadirnya peraturan yang sifatnya "abu-abu", tentu saja fenomena seperti ini perlu diperhatikan dan dipertimbangkan oleh pemerintah selaku penerbit peraturan dan pemungut pajak. 
Website : http://ekomaks.unmermadiun.ac.id/index.php/ekomaks

Adanya berbagai pendapat tersebut, membuat lembaga pendidikan tidak tinggal diam. Politeknik Negeri Madiun, dengan Pelatihan Brevet Pajaknya membekali para peserta dengan berbagai materi dan keahlian terupdate. Sehingga tantangan pada dunia kerja, khususnya dunia perpajakan akan dapat diatasi oleh lulusan brevet pajak Politeknik Negeri Madiun.

\section{IV.KESIMPULAN}

Berdasarkan hasil penelitian yang dilakukan, maka dapat disimpulkan, hadirnya PMK No 9 Tahun 2018 tentang surat pemberitahuan pajak terutang. Penjelasan PMK No 9 Tahun 2018 oleh konsultan pajak diketahui terdapat sisi positf dan negatif. Sisi positifnya adalah kemudahan dan sisi negatifnya adalah keterbatasan sumber daya manusia. Keberadaan peraturan pajak yang mengharuskan pelaporan pajak secara online lebih memudahkan, lebih paperless, bisa diakses kapanpun dan dimanapun. Semua partisipan sepakat dengan kesimpulan kemudahan adannya peraturan baru tersebut.

Pendapat lain dengan kritis menolak kehadiran peraturan yang dapat menimbulkan celah bagi wajib pajak. Terlebih hadirnya peraturan yang sifatnya "abu-abu", tentu saja fenomena seperti ini perlu diperhatikan dan dipertimbangkan oleh pemerintah selaku penerbit peraturan dan pemungut pajak.

Adanya berbagai pendapat tersebut, membuat lembaga pendidikan tidak tinggal diam. Politeknik Negeri Madiun, dengan Pelatihan Brevet Pajaknya membekali para peserta dengan berbagai materi dan keahlian terupdate. Sehingga tantangan pada dunia kerja, khususnya dunia perpajakan akan dapat diatasi oleh lulusan brevet pajak Politeknik Negeri Madiun.

\section{DAFTAR PUSTAKA}

Kuswarno, E. 2009. Metodologi Penelitian Komunikasi Fenomenologi, Konsepsi, Pedoman dan Contoh Penelitiannya. Bandung: Widya Padjajaran. Mardiasmo. 2011. Perpajakan. Yogyakarta: ANDI.

Miles, B. B., dan A. M. Huberman. 1992. Analisa Data Kualitatif. Jakarta: UI Press. Moleong, L.J. 2011. Metodologi Penelitian Kualitatif. Bandung: PT Remaja Rosdakarya.

PMK No 9 Tahun 2018 tentang Surat Pemberitahuan Pajak

Roekhudin. 2013. Ruwatan Sukerto: Studi Fenomenologi Transdental Respon Akuntan Internal, Akuntan Publik, dan Pengguna Laporan Keuangan Terhadap Fair Value Measurement, Disertasi tidak diterbitkan, Universitas Brawijaya, Malang.

Saad, N. 2014. Tax Knowledge, Tax Complexity and Tax Compliance : Taxpayers' View. Procedia - Social and Behavioral Sciences, $109(1), 1069-1075$.

Sapiei, N. S., dan Kasipillai, J. 2013. Impacts of the Self-Assessment System for Corporate Taxpayers. American Journal of Economics, 3(2), 75-81.

Smith, J.A., , P. Flower and M. Larkin. 2009. Interpretative Phenomenological Analysis: Theory, Method and Research. Undang-undang Republik Indonesia nomor 28 tahun 2007 tentang ketentuan umum dan tata cara perpajakan.

Undang-undang Republik Indonesia nomor 16 tahun 2009 tentang ketentuan umum dan tata cara perpajakan. Undang-undang Republik Indonesia No.36 tahun 2008 tentang pajak penghasilan.

https://finance.detik.com/berita-ekonomi-bisnis/d-3330166/sri-mulyani-target-penerimaan-perpajakan-2017-rp-1498-t-naik-15 (Diakses 4 April 2018, pukul 10:45) 